\title{
Climate-driven changes to streamflow patterns in a groundwater-dominated catchment
}

\author{
Urszula Somorowska ${ }^{1}$ (D)
}

Received: 26 February 2017/ Accepted: 8 June 2017/Published online: 13 June 2017

(C) The Author(s) 2017. This article is an open access publication

\begin{abstract}
This study aims to investigate trends and regime changes in streamflow and basic factors driving these changes. The investigated area is located in central Poland and is influenced by temperate transitional climate. New insight is provided into the phenomenon of past climatedriven changes to streamflow patterns over a 65 -year period (1951-2015). The Mann-Kendall test for monotonic trends and the CUSUM test are used to determine the presence or absence of changes in climatic variables, shallow groundwater level, and streamflow. Time series are explored to detect the direction of trends and the period when the significant change occurred. Differences in climatic conditions and streamflow patterns are discussed for two sub-periods, before and after the change. Overall, the results suggest stability in precipitation, with limited evidence for change in the annual amount, but reveal a significant change in streamflow regime in the 1980s, attributed to higher temperature driving evapotranspiration and reducing shallow groundwater recharge. It is concluded that the catchment is prone to increased evapotranspiration and in effect to greatly reduced runoff.
\end{abstract}

Keywords Streamflow regime - Climatic changes · Groundwater-dominated catchment · Central Poland

Urszula Somorowska

usomorow@uw.edu.pl

1 Department of Hydrology, Institute of Physical Geography, Faculty of Geography and Regional Studies, University of Warsaw, Krakowskie Przedmiescie 30, 00-927 Warsaw, Poland

\section{Introduction}

The natural streamflow regime is defined as the characteristic pattern of a river's flow quantity, timing, and variability (Poff et al. 1997). It may be identified by a seasonal variation in its streamflow and is usually characterized by a temporal pattern of monthly mean streamflow. It is widely accepted that the seasonal variation of river runoff depends on climate and catchment characteristics (Burt 2013). Important climatic factors include precipitation, air temperature, and evaporative demand controlling the recharge of surface and subsurface water storage and influencing the loss of water through evaporation. Other interacting factors responsible for the transformation of rainfall to runoff at a catchment scale are those related to topography, soil texture, groundwater aquifer, and vegetation cover. Because in human-dominated catchments, the covariation of anthropogenic and natural gradients in the landscape induces changes in streamflow regimes, threatening the ecological integrity of river ecosystems (Allan 2004), there is a growing need to better understand river regime changes and their drivers, both in semi-natural and human-influenced catchments (Tetzlaff et al. 2013; Schneider et al. 2013; Hall et al. 2014).

Numerous studies focus on catchments with semi-natural streamflow regimes to distinguish climate-driven changes from direct anthropogenic disturbances (e.g., Stahl et al. 2010; Hannaford and Buys 2012; Whitfield et al. 2012; Pumo et al. 2016). Studies on the river regime in catchments with little human impact might reveal the hydrologic response to variable climate characteristics in past and future conditions (Romanowicz et al. 2016). As the projections of future climate changes in Europe show changing precipitation patterns, an increase in evaporative demand with rising air temperatures, and a range of 
impacts on water resources (e.g., Bates et al. 2008), there is growing permanent interest in detecting changes in river flows (Stahl et al. 2012). The ability to anticipate such changes and their key drivers both for the past and the future is of foremost importance to design a framework for climate adaptation strategies for water resources management.

The regime changes of a river fed by shallow groundwater might be caused by a climate-related change in the groundwater level. The base flow component is usually significant in numerous lowland rivers in the temperate zone, where topographic gradients are relatively small and these rivers are fully or partially groundwater dependent (Sear et al. 1999; Boulton and Hancock 2006). Changes in local groundwater levels, initiated by a change in diffuse aquifer recharge through the vadose zone, might be a signal of alteration of groundwater discharge to the river (Loáiciga 2003). Abundant precipitation potentially increases the groundwater recharge, while in the case of intensified evaporation and decreased natural infiltration capacity soils may be responsible for the lowering of the groundwater table, even in the case of increased precipitation (Buczynski and Wcislo 2013). Although the significance of climate change has been widely recognized, detailed research on the impacts of climate change on groundwater resources is still relatively limited (Kumar 2012). The influence of climate conditions on the groundwater aquifers which are hydraulically connected to rivers remains poorly understood due to unknown groundwater residence time and uncertain delayed response (Green et al. 2011). There is still great potential for research on the influence of past climate over a long time scale to reveal natural groundwater variability on the basis of long-term monitoring networks (Kløve et al. 2014).

Trends in the streamflow series of Polish rivers have been investigated in numerous studies using different methods and varying temporal windows. The mean annual streamflow of two major rivers, the Vistula and the Oder, observed in the years 1901-2008, revealed no significant trend (Pociask-Karteczka 2011). Significant changes in the streamflow regime of the Warta River were detected over the years 1822-2005 (Wrzesiński 2010a). Two sub-periods with markedly low discharge (1856-1875) and exceptionally high discharge (1966-1985) were identified. Another study conducted in the Łasica catchment in the years 1951-2000 displayed a negative trend in annual runoff, accompanied by positive trends in precipitation and evapotranspiration (Gutry-Korycka 2003). Decreasing trends in the annual maximum runoff of lowland tributaries of the Liwiec and Wkra rivers were found in the years 1966-2000 (Szymczak 2005). Banasik and Hejduk (2012) showed decreasing trends in annual runoff and runoff coefficient in the years 1963-2010 in the small forested catchment of
Zagożdżonka River, accompanied by a lack of trend in precipitation. A negative trend in the spring maximum discharges of lowland rivers in Poland was explained by the impact of the North Atlantic Oscillation (Kaczmarek 2003). It influences meteorological variables and in consequence it modifies the streamflow regime (Wrzesinski $2010 b$ ). Occurrences of the mean maximum and minimum monthly air temperature were detected to be regular in years 1951-2000, while the timing of the highest and lowest monthly precipitation and streamflow appeared to be much less stable, as investigated in 168 catchments across Poland (Wrzesiński and Tomaszewski 2010). The most recent study by Jokiel (2016) showed continuously declining flood indexes derived from the maximum discharges registered at 71 water gauges in central Poland for the years 1951-2002. It was proved that the scale and the frequency of floods in the rivers of the lowland part of Poland were reduced.

With the possible consequences of climate-driven impacts to the sustainability of water resources in mind, the challenge is to provide evidence for changes in long-time series of hydrological data (Kundzewicz 2004). Given the importance of freshwater resources to the environment and society, numerous studies undertook efforts to increase the understanding of how changes in rainfall and air temperature influence streamflow regimes and how these changes might act in the future (e.g., Meresa et al. 2016; Osuch et al. 2016).

The main aim of the present contribution is to provide evidence for past changes in climate variables in a lowland groundwater-dominated river catchment in the temporal transitional climate in central Poland, and detect the climate change significance in streamflow series. The investigations span over a 65-year-long period, covering the years 1951-2015. An attempt was made to study the trendtype changes in the annual and seasonal climatic series, to identify the turning year in which the river regime has changed and to compare the streamflow parameters in the pre-change and the post-change period.

\section{Study area and data}

The study concerns the Łasica catchment, which is situated in the Mazovian Lowland, with a temperate transitional climate in central Poland. The study area is located between $52^{\circ} 13^{\prime} \mathrm{N}$ and $52^{\circ} 24^{\prime} \mathrm{N}$, and $20^{\circ} 15^{\prime} \mathrm{E}$ and $20^{\circ} 57^{\prime} \mathrm{E}$ (Fig. 1). The gauging station is situated at the Władysławów cross section and closes the catchment of $343 \mathrm{~km}^{2}$. The altitude ranges from $65 \mathrm{~m}$ near Władysławów to $130 \mathrm{~m}$ in the eastern part of the catchment. A considerable part of the catchment in situated in the Kampinos National Park (KNP), which is classified as a biosphere reserve. The KNP is famous for its 
Fig. 1 Location of the Łasica catchment, central Poland Also shown are the altitudes acquired from the SRTM (Jarvis et al. 2008)

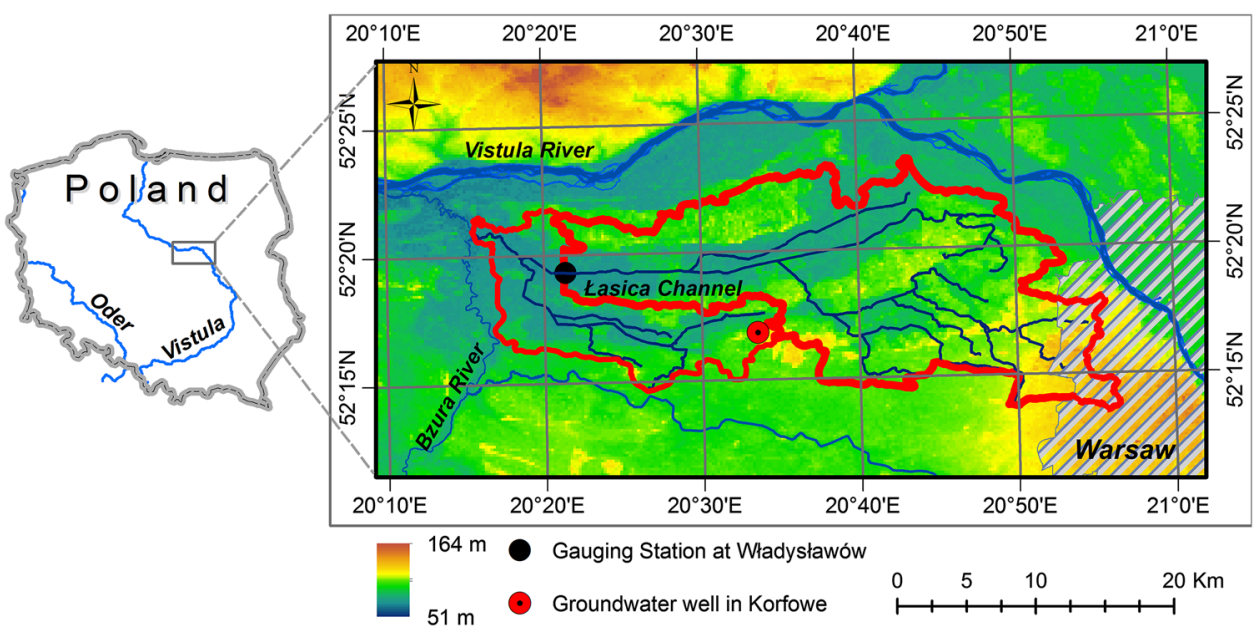

complexes of peat bogs with shallow groundwater level, separated by the wooded dunes. The natural river network has been supplemented in the past by an artificial channel network, stimulating the discharge from naturally flat wetland areas. The major changes took place between 1850 and 1870 , followed by the installment of field drain systems and the regulation of the Vistula Valley in the period 1900-1950 (Gutry-Korycka and Golebiowska 2015). In effect, the drainage system of the Łasica channel due to the riverbed regulation was stabilized in the 1950s. Later on, in the 1970s, construction of some weirs on the main channel and its tributaries took place. Other changes resulting from deforestation were mainly introduced in the nineteenth century. Starting from the 1950s onward, the catchment was affected by relatively few improvements in riverbed regulations, and since the 1970s it was fully protected within the boundaries of the Kampinos National Park. Currently, strategies aiming at reducing the drainage in areas with limited water resources are being considered (Mioduszewski et al. 2010; Kubrak et al. 2011). The main aim is to reduce the level of degradation of habitats through renaturation measures (Piniewski et al. 2012; Kopeć et al. 2013). The river has a very welldeveloped nival regime characteristic in the lowland part of Poland (Wrzesiński 2016). It is characterized by high flows due to snowmelt in spring, followed by a rapid recession of river runoff, and transitioning to low flows in the summerautumn season. Approximately, $96 \%$ of the total discharge is baseflow, and only the remaining $4 \%$ is surface runoff (Somorowska 2006).

Data used in this study comprise daily data of precipitation, maximum and minimum air temperature, streamflow, and groundwater level in the period 1951-2015. Precipitation and air temperature data were acquired from the CHASE database prepared with the spatial resolution of $5 \mathrm{~km}$ (Berezowski et al. 2016) for the years 1951-2013 and supplemented with values obtained from the E-OBS gridded data set prepared and released by the European Climate Assessment \& Dataset
Project (Haylock et al. 2008). After acquiring the data series, areal weighted estimates of precipitation and air temperature over the catchment were calculated by using selected grid point values (Fig. 2). Daily streamflow data for the whole period of analysis have been made available by the Institute of Meteorology and Water Management, National Research Institute in Warsaw, Poland (IMGW-PIB).

Groundwater level records from observation wells belonging to the monitoring network of the Kampinos National Park were used in the analysis (Fig. 2). Groundwater level data are available since 1998, when the network started its operation, and represent the depth below the ground surface of the water table measured every 2 weeks. All groundwater observation wells are located in the unconfined aquifer and are recharged due to rainfall. Moreover, weekly historic groundwater records from the well located in Korfowe $\left(52^{\circ} 16^{\prime} \mathrm{N}, 20^{\circ} 31^{\prime} \mathrm{E}\right)$ have been acquired for the period 1951-2000 from the IMGW-PIB. This data have served as a long-term benchmark for the reconstruction of groundwater level in the catchment in the period 1951-1997. Using the relationship between the groundwater level in Korfowe and the mean groundwater level in lowland, wet zones in the years 1998-2000, the monthly values of groundwater level in lowland zones were reconstructed for the period 1951-1997. Thus, in this study the analysis of groundwater level concerned the whole period 1951-2015.

Daily data of precipitation, temperature, potential evapotranspiration, and streamflow have been aggregated to monthly, seasonal, and annual values in the hydrological years 1951-2015. Daily reference evapotranspiration, here called potential evapotranspiration, was calculated using the FAO Penman-Monteith method (Raes 2012). To account for the seasonality behavior of streamflow, the analysis was conducted by dividing the hydrological year into two seasons, namely the winter (November-April) and the summer (May-October) season. Daily precipitation and evapotranspiration were summed up to monthly, seasonal, 
Fig. 2 Locations of groundwater wells from the KNP Monitoring Network and grid points from the meteorological databases. Land use is derived from CLC 2012 acquired at http://clc.gios.gov. $\mathrm{pl} /$

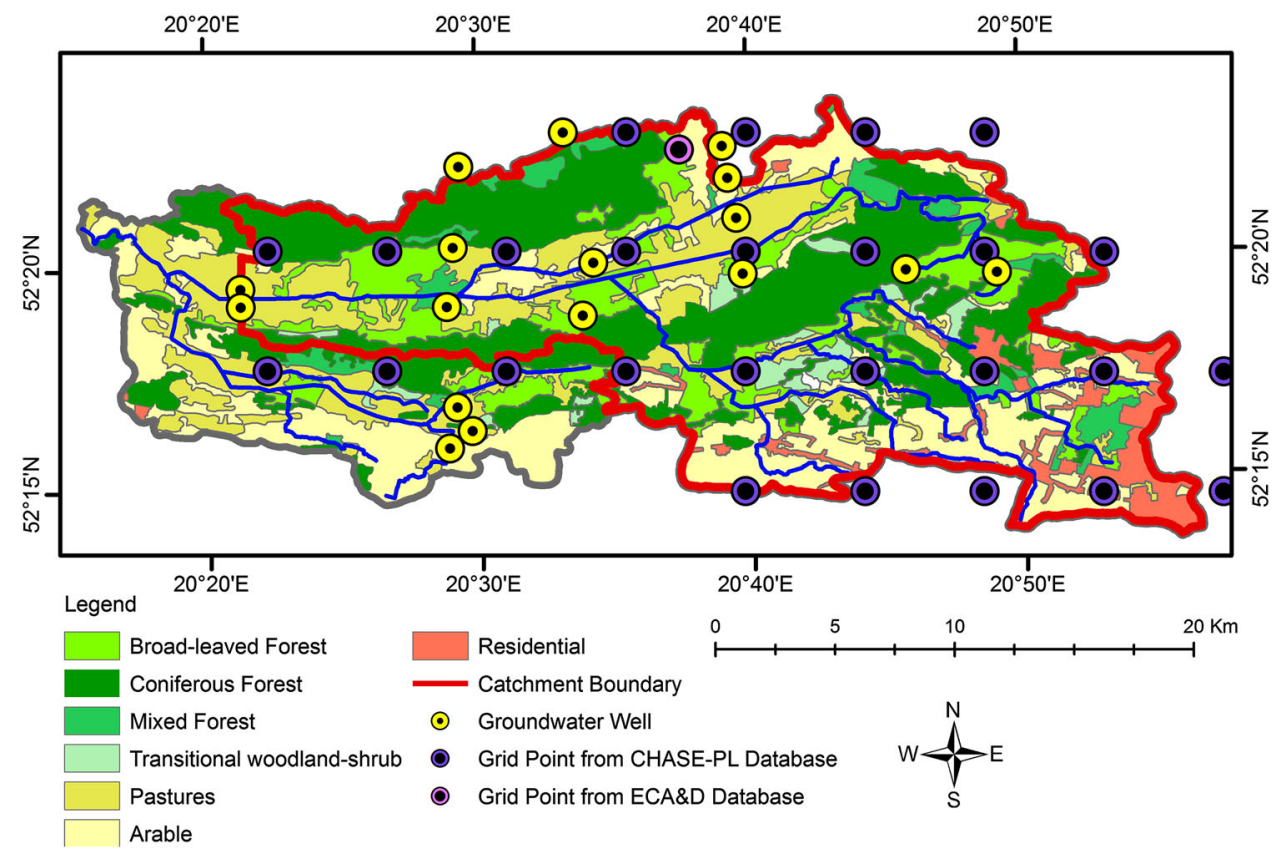

and annual values. Mean monthly and mean maximum air temperatures were calculated from daily values and then the annual means (mean annual temperature and mean annual maximum temperature, respectively) were derived. Analogically, monthly, seasonal, and annual streamflow averages were calculated.

The E-OBS precipitation ( $\left.\mathrm{P}_{\mathrm{E}-\mathrm{OBS}}\right)$ series, which are not corrected for measurement bias, shows a systematic underestimation when compared with the CHASE precipitation $\left(\mathrm{P}_{\mathrm{CHASE}}\right)$ series, corrected for snowfall and rainfall undercatch. The dependence between monthly $\mathrm{P}_{\mathrm{CHASE}}$ and $\mathrm{P}_{\mathrm{E}-\mathrm{OBS}}$ series (1951-2013) was quantified by the Pearson's correlation coefficient which ranged from 0.84 to 0.98 . To ensure consistency, monthly $\mathrm{P}_{\mathrm{E}-\mathrm{OBS}}$ series for the years 2014-2015 were adjusted by multiplying them by the monthly correction factor estimated as $\mathrm{C}=\mathrm{P}_{\mathrm{CHASE}} / \mathrm{P}_{\mathrm{E}-\mathrm{OBS}}$ for the years 1951-2013. It ranged from 1.280 to 1.564 for November to April and from 1.136 to 1.240 for May to October. Similar adjustment for monthly values was conducted for air temperature series. In case of maximum air temperature series, the correlation coefficient ranged from 0.98 to 0.99 , and the correction factor ranged from 0.97 to 1.01 , equaling 1.00 in most cases. In case of mean air temperature series, the correlation coefficient was also very high, ranging from 0.97 to 0.99 , and the correction factor varied from 0.98 to 1.08 .

\section{Methods}

Climatic and hydrologic characteristics were examined for trend-type changes using the Mann-Kendall (MK) trend test. Temporal trends were evaluated for the entire 65-element record with a significance level $(p)$ of 0.95 . The test was performed to analyze long-term changes in precipitation, air temperature, potential evapotranspiration, streamflow, and shallow groundwater level. The MK test is one of the most commonly used for hydro-meteorological time series trend detection (Radziejewski and Kundzewicz 2004a). The HYDROSPECT software (Radziejewski and Kundzewicz 2004b) was used to calculate the MannKendall test statistic $(Z)$ and the statistical significance. Negative values of $Z$ indicate decreasing trends, while positive $Z$ values characterize increasing trends. A high value of the computed significance level means that the hypothesis of a lack of change is rejected, and there is a high chance that a change exists. If a serial correlation in a time series data was found, bootstrapping resampling method was used before conducting the MK test (Kundzewicz and Radziejewski 2006). In addition, the magnitude of a trend (rate of change) was estimated by the KendallTheil robust line (Theil 1950; Helsel and Hirsch 2002).

For the shift-type changes in streamflow series, the nonparametric, distribution-free CUSUM test (Kundzewicz and Robson 2004; Radziejewski and Kundzewicz 2004a) was used to determine the turning year (change point). The turning year divides the dataset into sub-periods that differ from each other by their mean values. The turning year (change point) approach was formerly used in hydrologic studies by, e.g., Ehsanzadeh et al. (2011), Yang et al. (2012) and, Rodionov and Overland (2005). In this study, turning points were identified in a series of annual streamflows, winter streamflow, summer streamflow, annual maximum streamflow, and annual minimum streamflow, using the HYDROSPECT software 
(Radziejewski and Kundzewicz 2004b). The KruskalWallis test was performed to test for statistically significant differences between the two sub-period means. The relationship between the magnitude and frequency of streamflow was analyzed using the flow duration curve (FDC) in pre-change and post-change periods.

\section{Results}

\section{Changes in time series under a monotonic trend assumption}

A series of annual $\left(\mathrm{P}_{\text {Nov-Oct }}\right)$ and summer-half precipitation $\left(\mathrm{P}_{\text {May-Oct }}\right)$ do not show a statistically significant change (Table 1), whereas a statistically significant positive trend is found in the series of winter-half precipitation $\left(\mathrm{P}_{\mathrm{Nov}-\mathrm{Apr}}\right)$. However, its rate of change is relatively small, accounting for $6 \mathrm{~mm} /$ decade. Statistically significant positive trends are found in the time series of mean annual temperature (TM) and mean annual maximum temperature (TX). The highest rate of change in temperature concerns the winter half of the year, with a change of approximately $0.3-0.4{ }^{\circ} \mathrm{C} /$ decade. In consequence, the annual potential evapotranspiration (ETP) shows a significant upward trend with a rate of change of $9.5 \mathrm{~mm} /$ decade. Contrasting to those are negative trends found in groundwater levels. This concerns a series of annual mean and summer-half mean, showing a decrease of approximately 30-40 mm/decade, whereas the winter-half groundwater levels only show a negative tendency. Following the detection of changes in climatic and groundwater variables, the decrease of streamflow was determined for all three considered series $\left(\mathrm{Q}_{\text {Nov-Oct }}, \mathrm{Q}_{\text {Nov-Apr }}\right.$, and $\left.\mathrm{Q}_{\text {May-Oct }}\right)$ during the entire period of analysis.

\section{Detection of turning year (change point) in streamflow series}

As results of the monotonic MK test for streamflow series indicated that the change occurred over the time period in question, additionally the CUSUM test was applied to detect the shift-type changes. A change point indicates the time of the abrupt change in streamflow. All of the five investigated streamflow parameters exhibited a significant change in 1982 (Fig. 3; Table 2). Following the change point detection in the streamflow series, the mean monthly climatic and hydrologic characteristics were evaluated in two distinguished sub-periods of the entire period of analysis (1951-2015) to provide an explanation into the controlling factors of hydrologic change. The sub-period before the change is called period 1 (1951-1982), and the sub-period after the change is called period 2 (1983-2015). The Kruskal-Wallis test was used to determine the
Table 1 Summary statistics of the MK test applied to climatic and hydrologic variables in years 1951-2015

\begin{tabular}{|c|c|c|c|}
\hline Time series & MK statistic $(Z)$ & $\begin{array}{l}\text { Significance } \\
\text { level } p(\%)\end{array}$ & $\begin{array}{l}\text { Rate of change }\left(\mathrm{mm}_{\mathrm{m}} \mathrm{year}^{-1}\right) \\
\left({ }^{\circ} \mathrm{C} \text { year }^{-1}\right)^{*}\left(\mathrm{~m}^{3} \text { year }^{-1}\right)^{* *}\end{array}$ \\
\hline $\mathrm{P}_{\mathrm{Nov}-\mathrm{Oct}}$ & 1.025 & 69.45 & 0.714 \\
\hline $\mathrm{P}_{\text {Nov-Apr }}$ & 2.265 & 97.64 & 0.742 \\
\hline $\mathrm{P}_{\text {May-Oct }}$ & 0.379 & 29.55 & 0.182 \\
\hline $\mathrm{TX}_{\text {Nov-Oct }}$ & 3.996 & 99.95 & $0.029 *$ \\
\hline $\mathrm{TX}_{\text {Nov-Apr }}$ & 3.286 & 99.89 & $0.038 *$ \\
\hline $\mathrm{TX}_{\text {May-Oct }}$ & 3.103 & 99.80 & $0.020 *$ \\
\hline $\mathrm{TM}_{\text {Nov-Oct }}$ & 3.850 & 99.95 & $0.025 *$ \\
\hline $\mathrm{TM}_{\text {Nov-Apr }}$ & 3.002 & 99.95 & $0.033^{*}$ \\
\hline $\mathrm{TM}_{\text {May-Oct }}$ & 3.539 & 99.95 & $0.018 *$ \\
\hline $\mathrm{ETP}_{\mathrm{Nov}-\mathrm{Oct}}$ & 3.481 & 99.95 & 0.945 \\
\hline ETP $_{\text {Nov-Apr }}$ & 3.920 & 99.95 & 0.400 \\
\hline $\mathrm{ETP}_{\text {May-Oct }}$ & 2.605 & 98.75 & 0.539 \\
\hline $\mathrm{GR}_{\mathrm{Nov}-\mathrm{Oct}}$ & -2.743 & 99.39 & -3 \\
\hline $\mathrm{GR}_{\text {Nov-Apr }}$ & -0.635 & 47.43 & -1 \\
\hline $\mathrm{GR}_{\text {May-Oct }}$ & -3.065 & 99.78 & -4 \\
\hline $\mathrm{Q}_{\text {Nov-Oct }}$ & -2.270 & 97.45 & $-0.007 * *$ \\
\hline $\mathrm{Q}_{\text {Nov-Apr }}$ & -2.332 & 98.30 & $-0.009 * *$ \\
\hline $\mathrm{Q}_{\text {May-Oct }}$ & -1.948 & 94.85 & $-0.004 * *$ \\
\hline
\end{tabular}

Rate of change was evaluated by Kendall-Theil robust line

$P$ precipitation, $T X$ mean maximum air temperature, $T M$ mean air temperature, ETP potential evapotranspiration, $G W$ depth to groundwater table, $Q$ flow rate 
Fig. 3 Streamflow time series in the period 1951-2015, with a change point in 1982

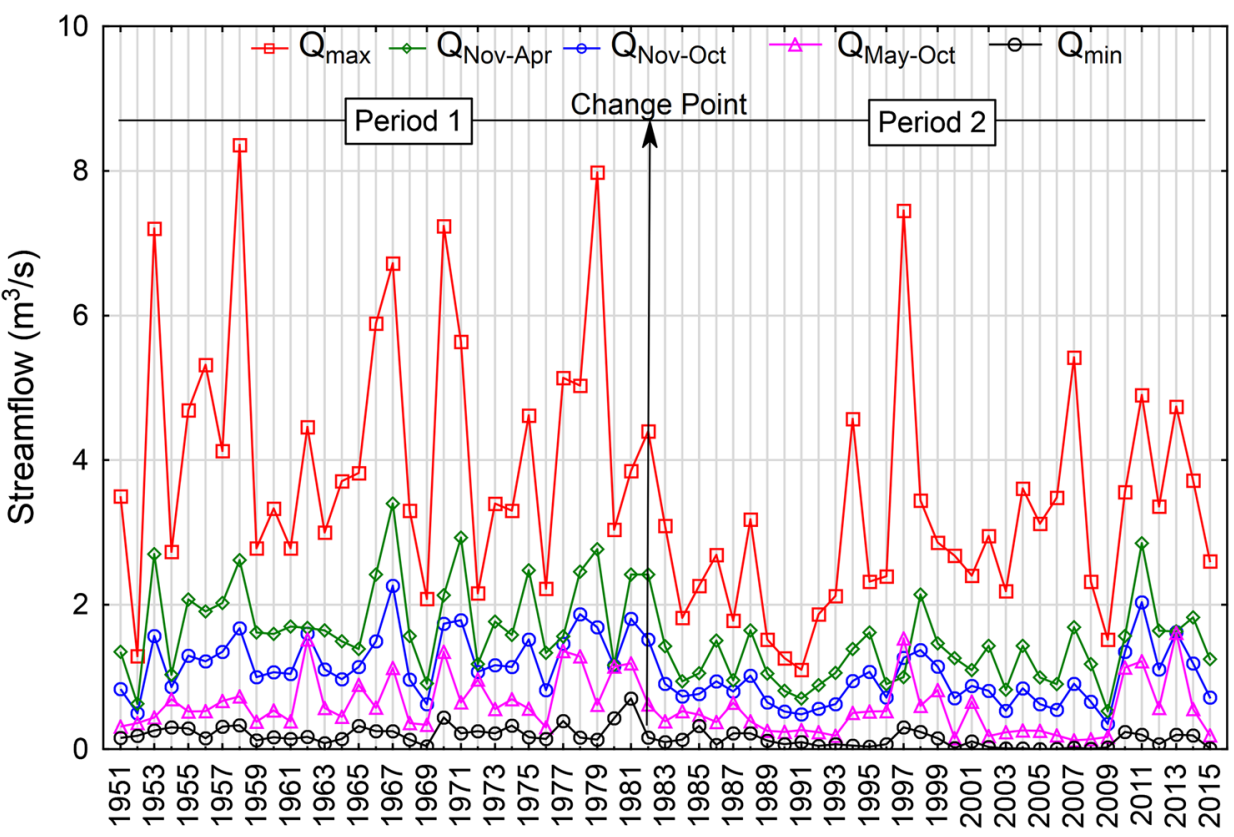

Table 2 Summary statistics of the CUSUM and Kruskal-Wallis tests applied to flow metrics

\begin{tabular}{llllll}
\hline Time series & CUSUM statistic & Significance level $p(\%)$ & Change point (year) & Kruskal-Wallis statistic & Significance level $p(\%)$ \\
\hline Q $_{\text {Nov-Oct }}$ & 0.469 & 99.95 & 1982 & 13.865 & 99.95 \\
Q $_{\text {Nov-Apr }}$ & 0.438 & 99.85 & 1982 & 11.751 & 99.85 \\
$Q_{\text {May-Oct }}$ & 0.365 & 98.10 & 1982 & 9.087 & 99.75 \\
$Q_{\max }$ & 0.366 & 97.25 & 1982 & 9.206 & 99.75 \\
$Q_{\min }$ & 0.469 & 99.95 & 1982 & 18.972 & 99.95 \\
\hline
\end{tabular}

$Q_{\text {Nov-Oct }}$ mean annual flow rate, $Q_{N o v-A p r}$ mean flow rate in the winter season, $Q_{M a y-O c t}$ mean flow rate in the summer season, $Q_{m a x}$ annual maximum flow rate, $Q_{\min }$ annual minimum flow rate

significance of the difference between the average values of streamflow parameters in period 1 and period 2. The mean annual streamflow in period 1 was $1.290 \mathrm{~m}^{3} / \mathrm{s}$, decreasing to $0.899 \mathrm{~m}^{3} / \mathrm{s}$ in period 2 . The mean winter-half streamflow also decreased from $1.871 \mathrm{~m}^{3} / \mathrm{s}$ in period 1 to $1.291 \mathrm{~m}^{3} / \mathrm{s}$ in period 2. A similar tendency was observed in the mean summer-half streamflow, with a decrease in mean from 0.708 to $0.488 \mathrm{~m}^{3} / \mathrm{s}$. The mean annual maximum streamflow in period 1 was $4.285 \mathrm{~m}^{3} / \mathrm{s}$, reducing to $2.978 \mathrm{~m}^{3} / \mathrm{s}$ in period 2 . With reference to the mean annual minimum streamflow values in the respective periods, a decrease occurred from 0.708 to $0.488 \mathrm{~m}^{3} / \mathrm{s}$.

\section{Climatic factors influencing groundwater and streamflow patterns}

Potential evapotranspiration is responsible for losses in groundwater resources. Precipitation is considered as a climatic driving force of groundwater recharge influencing groundwater discharge to the river and in effect determining river flows. Increase of precipitation might increase the catchment recharge, though this effect might not occur if accompanied by a significant increase in air temperature influencing increase of evaporation. Changes in streamflow patterns are analyzed here in the context of the combination of the changes in climatic factors and groundwater level.

Generally, period 1 (1951-1982) was slightly cooler then period 2 (1983-2015), as shown in Fig. 4e, f. The mean daily air temperature in period 1 amounted to $7.8^{\circ} \mathrm{C}$, and in period 2 to $28.6^{\circ} \mathrm{C}$. The mean daily air temperature in the winter season differed by $1.1^{\circ} \mathrm{C}$ in the two periods ( 0.9 and $2.0{ }^{\circ} \mathrm{C}$ in period 1 and period 2 , respectively), while in the summer season by $0.6{ }^{\circ} \mathrm{C}\left(14.6\right.$ and $15.2^{\circ} \mathrm{C}$, respectively). Much higher differences occurred in the mean daily maximum temperature, amounting to $1,1.3$, and $0.7{ }^{\circ} \mathrm{C}$ for the entire year, winter half year, and summer half year, respectively. In effect, annual potential evapotranspiration increased on average from 695 to $728 \mathrm{~mm}$ (Fig. 4c). However, by definition, this figure only provides a picture of atmospheric demand and not the actual amount dependent on the availability of water in the 
(a)

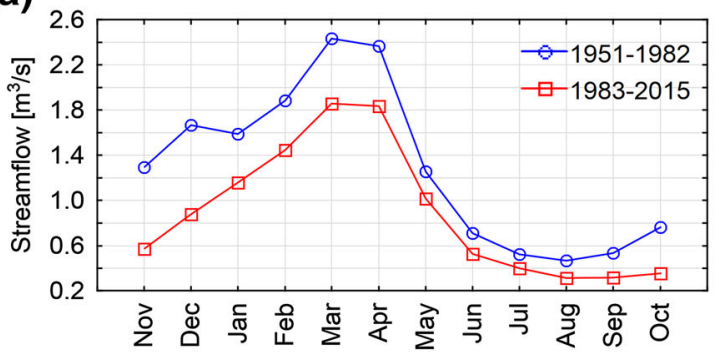

(b)

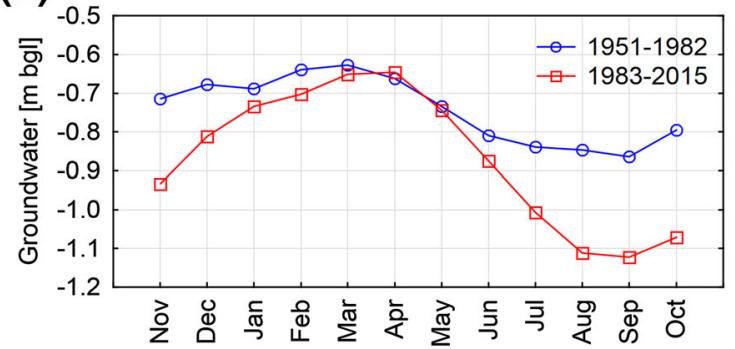

(c)

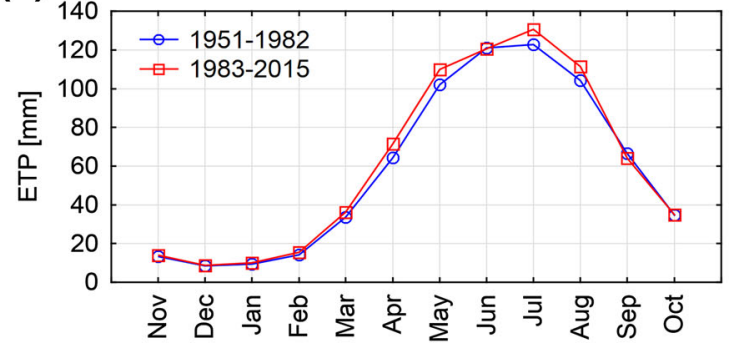

(d)

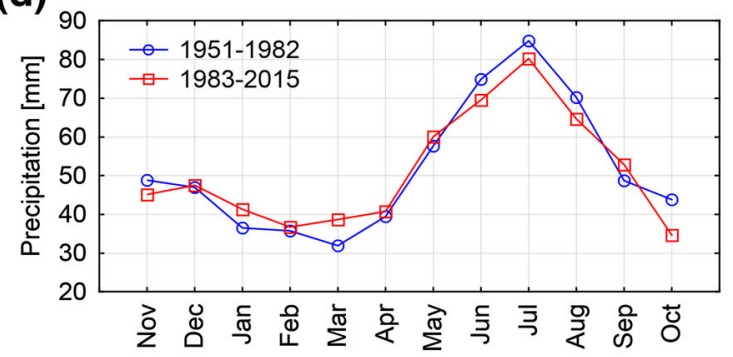

(e)

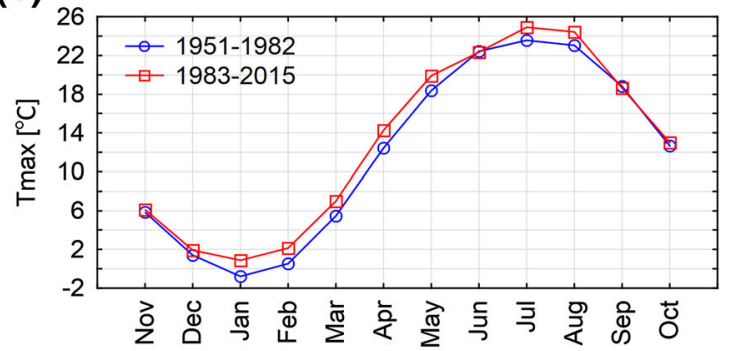

(f)

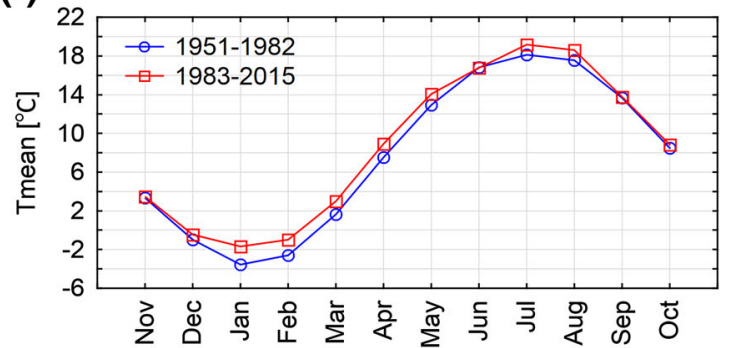

Fig. 4 Mean monthly streamflow (a), groundwater level (b), potential evapotranspiration (c), precipitation (d), maximum air temperature (e), and mean air temperature (f) in the Łasica River catchment for 1951-1982 and 1983-2015

subsurface. A comparison of annual precipitation in two periods did not reveal a significant change (Fig. 4d). The mean annual precipitation was 620 and $612 \mathrm{~mm}$ in the respective periods. Only relatively higher precipitation occurred in the winter half year of period 2, accompanied by slightly lower precipitation in the summer half year.

A net effect of changes in climatic variables was observed in changes of temporal patterns of shallow groundwater level (Fig. 4b). A lowering of the groundwater level occurred in period 2 almost throughout the entire year. The highest difference of the order of $25 \mathrm{~cm}$ was observed in the months from August to November. Groundwater level in March and April in period 2 follows the pattern in period 1. The rise of groundwater level starts in October and lasts until March-April, and is then followed by a recession until August-September. The recession leads to much lower groundwater level in period 2. In consequence, changes in the seasonal pattern of streamflow supplied from lowered groundwater storage may be observed (Fig. 4a). The mean monthly hydrograph for the entire hydrological year in period 2 is much below that for period 1. The mean annual streamflow was $1.29 \mathrm{~m}^{3} / \mathrm{s}$
$(119 \mathrm{~mm})$ in period 1 and $0.89 \mathrm{~m}^{3} / \mathrm{s}(82 \mathrm{~mm})$ in period 2 . In effect, the river runoff coefficient decreased from 19 to $13 \%$. Thus, the mean annual difference in streamflow between the two periods was $0.40 \mathrm{~m}^{3} / \mathrm{s}$. Although high differences appeared and drying signals were observed by lowered groundwater level and lower streamflow in period 2 in comparison with period 1 , the timing of mean monthly maximum and minimum values of climatic and hydrologic characteristics was maintained.

\section{Changes in flow duration curves}

Changes in streamflow in two distinguished sub-periods are quite significant over the entire discharge spectrum (Fig. 5). FDCs, which were presented on logarithmic scale, revealed that the magnitude of streamflow of particular exceedance probability evidently decreased in period 2 . Especially for $\mathrm{Q}_{95}$, which is streamflow equaled or exceeded for $95 \%$ of the time, it decreased from 0.215 to $0.032 \mathrm{~m}^{3} / \mathrm{s}$, so by $85 \%$. For $\mathrm{Q}_{5}$ and $\mathrm{Q}_{50}$, representing streamflow equaled or exceeded for 5 and $50 \%$ of the time, it decreased by 24 and $34 \%$, respectively. Considering 


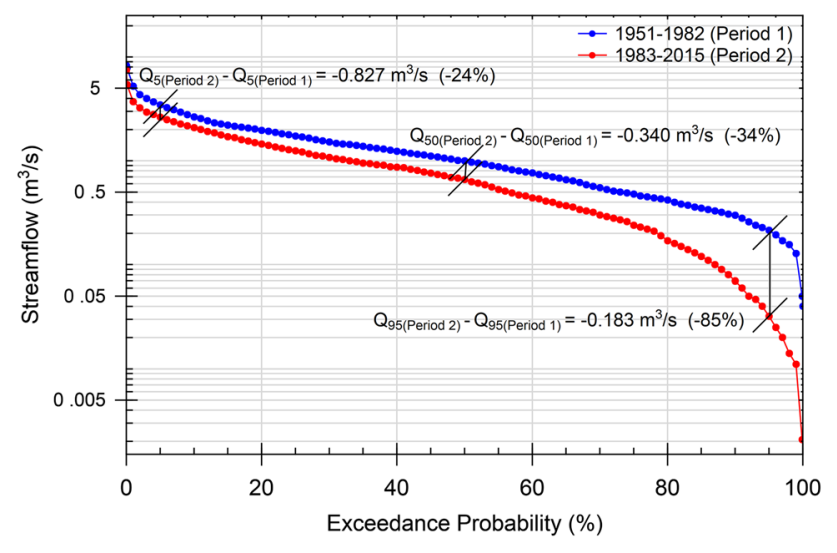

Fig. 5 Flow duration curves for 1951-1982 and 1983-2015

$0.50 \mathrm{~m}^{3} / \mathrm{s}$ as the mean monthly streamflow for AugustSeptember in period 1 , the exceedance probability decreased from $73 \%$ in period 1 to $56 \%$ in period 2, which means that the occurrence of low streamflow is more frequent in period 2. Considering $2.43 \mathrm{~m}^{3} / \mathrm{s}$ as the mean monthly streamflow for March in period 1 as the start of the snowmelt season, the exceedance probability dropped almost double, from $12 \%$ to approximately $6.5 \%$.

\section{Discussion}

The investigation concerned the streamflow response in the Łasica catchment due to climate variability over the longterm period spanning from 1951 to 2015. Following the changes in climatic variables, a change in the mean annual streamflow is observed, while the timing of mean monthly streamflow is preserved. Major changes are apparent, which concern overall streamflow reduction. $\mathrm{Q}_{95}, \mathrm{Q}_{50}$, and $\mathrm{Q}_{5}$, representing, respectively low, median and high streamflow, decreased considerably in period 2 .

An increase in actual evapotranspiration is considered as a possible factor responsible for reduced groundwater recharge, and, in consequence, for reduced groundwater discharge to the river drainage system. Increasing trends in maximum, minimum, and mean air temperatures are apparent, all of them having significant effect in terms of precipitation absorbed by vegetation and transpired by plants to the atmosphere. An approximate estimation of actual evapotranspiration as a difference between mean annual precipitation and mean annual discharge in two periods (period 1 and period 2) reveals an increase of evapotranspiration in period 2 by $29 \mathrm{~mm}$. Thus, it can be concluded that the catchment is prone to increased evapotranspiration and in effect to greatly reduced runoff. It is worth mentioning that the increase of evapotranspiration depends not only on changing meteorological conditions, but also on the internal catchment behavior dependent on the vegetation dynamics. Nowadays, the area covered by wetland habitats is dominated by mesic and dry vegetation communities; however, natural plants (reed beds and sedges) started to grow and vegetation regeneration can be observed (Kopeć et al. 2013). Thus, quantifying the effect of vegetation change on streamflow is a challenge, but the availability of consistent data on water use by vegetation is a limiting factor in the multi-year analysis.

\section{Conclusions}

The changes in climatic and hydrologic variables were assessed based on trend-type and change point analysis methods. Statistically significant increasing trends over the period 1951-2015 were detected in the annual series of air temperature, and potential evapotranspiration with a slight upward trend occurred for winter-half precipitation. Significant change in streamflow parameters appeared to be apparent in 1982, which was detected as the turning year in the river regime. The annual discharge is reduced by $31 \%$, referring to mean annual discharge in period 1 (1951-1982) before the turning year to its value in period 2 (1983-2015), after the change. The flow duration curve demonstrated that low streamflow occurrence is more frequent in the period after the change. The analysis illustrates that changes in climatic variables have an effect on reduced groundwater recharge, an increase in evapotranspiration, and in effect cause the reduction in runoff.

Due to changes in precipitation and air temperature projected for the near-future 2021-2050 and far-future 2071-2100, further changes in streamflow can occur in the Łasica catchment (Meresa et al. 2016). Standardized Precipitation-Evapotranspiration Index predicts drier conditions while Standardized Precipitation Index indicates wetter climate. Considering the Standardized Runoff Index, drier conditions are predicted for the far future compared to the reference period 1971-2000. Increasing atmospheric demand might further increase potential evapotranspiration, while low soil water content might be responsible for reduction of transpiration. Thus, future streamflow changes will reflect net hydrological behavior of the catchment responding both to climate and vegetation dynamics.

Acknowledgements The author acknowledges the anonymous reviewers and the editors for their insightful comments and helpful suggestions. The author acknowledge the E-OBS dataset from the EU-FP6 project ENSEMBLES (http://ensembles-eu.metoffice.com) and the data providers in the ECA\&D project (http://www.ecad.eu). Also, the author wishes to acknowledge the CHASE-PL Forcing Data: Gridded Daily Precipitation \& Temperature Dataset 5 km (CPLFDGDPT5), doi:10.4121/uuid:e939aec0-bdd1-440f-bd1e-c49ff10d0a07. The Institute of Meteorology and Water Management, National Research Institute (IMGW-PIB) in Warsaw is acknowledged for 
providing the streamflow data and, finally, the Kampinos National Park is thanked for providing the groundwater data.

Open Access This article is distributed under the terms of the Creative Commons Attribution 4.0 International License (http://crea tivecommons.org/licenses/by/4.0/), which permits unrestricted use, distribution, and reproduction in any medium, provided you give appropriate credit to the original author(s) and the source, provide a link to the Creative Commons license, and indicate if changes were made.

\section{References}

Allan JD (2004) Landscapes and riverscapes: the influence of land use on stream ecosystems. Annu Rev Ecol Evol Syst 35:257-284

Banasik K, Hejduk L (2012) Long-term changes in runoff from a small agricultural catchment. Soil Water Res 7:64-72

Bates BC, Kundzewicz ZW, Wu S, Palutikof JP (2008) (eds) Climate change and water, Technical Paper of the Intergovernmental Panel on Climate Change, IPCC Secretariat, Geneva, 3-4

Berezowski T, Szcześniak M, Kardel I, Michałowski R, Okruszko T, Mezghani A, Piniewski M (2016) CPLFD-GDPT5: high-resolution gridded daily precipitation and temperature data set for two largest Polish river basins. Earth Syst Sci Data 8:127-139

Boulton AJ, Hancock PJ (2006) Rivers as groundwater-dependent ecosystems: a review of degrees of dependency, riverine processes and management implications. Aust J Bot 54:133-144

Buczyński S, Wcislo M (2013) Predicting climate-induced changes in groundwater resources on the basis of hydrogeological model research: case study of the Carpathian flysch belt. Episodes 36(2): 105-114

Burt TM (2013) The silent river: the hydrological basis for river conservation. In: Sabater S, Elosegi A (eds) River conservation. Challenges and opportunities. Fundación BBVA, Bilbao, pp 39-60

Ehsanzadeh E, Ouarda TBMJ, Saley HM (2011) A simultaneous analysis of gradual and abrupt changes in Canadian low streamflows. Hydrol Process 25:727-739

Green TR et al (2011) Beneath the surface of global change: impacts of climate change on groundwater. J Hydrol 405(3-4):532-560

Gutry-Korycka M (2003) Long-term tendencies in water circulation in the Łasica river basin. Ecohydrol Hydrobiol 3(3):351-358

Gutry-Korycka M, Golebiowska I (2015) Hydrological alteration of an ice-marginal valley and its influence on the extent of historical floods. Hydrol Sci J 60(3):482-497

Hall $\mathrm{J}$ et al (2014) Understanding flood regime changes in Europe: a state-of-the-art assessment. Hydrol Earth Syst Sci 18:2735-2772

Hannaford J, Buys G (2012) Trends in seasonal river flow regimes in the UK. J Hydrol 475:158-174

Haylock MR et al (2008) A European daily high-resolution gridded dataset of surface temperature and precipitation. JGR 113:D20119

Helsel DR, Hirsch RM (2002) Statistical methods in water resources. Techniques of Water Resources Investigations, Book 4, Chapter A3, USGS

Jarvis A, Reuter HI, Nelson A, Guevara E (2008) Hole-filled SRTM for the globe Version 4, CGIAR-CSI SRTM $90 \mathrm{~m}$ Database. Source: http://srtm.csi.cgiar.org

Jokiel P (2016) Przepływy i odpływy maksymalne w środkowej Polsce. Geogr Tour 4(2):7-21

Kaczmarek Z (2003) The impact climate variability on flood risk in Poland. Risk Anal 23:559-566

Kløve B et al (2014) Climate change impacts on groundwater and dependent ecosystems. J Hydrol 518:250-266
Kopeć D, Michalska-Hejduk D, Krogulec E (2013) The relationship between vegetation and ground water levels as an indicator of spontaneous wet land restoration. Ecol Eng 57:242-251

Kubrak J, Mioduszewski W, Kowalewski Z, Okruszko T (2011) Możliwości wykorzystania istniejących i projektowanych budowli na Kanale Łasica do kształtowania warunków uwilgotnienia gleb w Kampinoskim Parku Narodowym. Woda Środowisko Obszary Wiejskie 11(3):123-135

Kumar CP (2012) Climate change and its impacts on the groundwater resources. Int J Eng Sci 1:43-60

Kundzewicz ZW (2004) Editorial-searching for change in hydrological data. Hydrol Sci J 49(1):3-6

Kundzewicz ZW, Radziejewski M (2006) Methodologies for trend detection. In: Demuth S, Gustard A, Planos E, Scatena F, Servat E (eds) Climate variability and change-hydrological impacts. Proceedings of the fifth FRIEND World Conference, Havana, Cuba 2006, vol 308. IAHS Publications, Wallingford, pp 538-549

Kundzewicz ZW, Robson AJ (2004) Change detection in river flow records-a review of the methodology. Hydrol Sci J 49(1):7-19

Loáiciga HA (2003) Climate change and ground water. Ann Assoc Am Geogr 93(1):30-41

Meresa HK, Osuch M, Romanowicz R (2016) Hydro-meteorological drought projections into the 21-st century for selected polish catchments. Water 8(5):206

Mioduszewski W, Kowalewski Z, Żurawski R, Stankiewicz J (2010) Drainage system in the Kampinos National Park. J Water Land Dev 14:83-95

Osuch M, Romanowicz RJ, Lawrence D, Wong WK (2016) Trends in projections of standardized precipitation indices in a future climate in Poland. Hydrol Earth Syst Sci 20:1947-1969

Piniewski M, Gottschalk L, Krasovskaia I, Choromanski J (2012) A GIS-based model for testing effects of restoration measures in wetlands: a case study in the Kampinos National Park, Poland. Ecol Eng 44:25-35

Pociask-Karteczka J (2011) River runoff response to climate changes in Poland (East-Central Europe). IAHS Publ 344:182-187

Poff NL et al (1997) The natural flow regime: a paradigm for conservation and restoration of riverine ecosystems. Bioscience 47:769-784

Pumo D, Caracciolo D, Viola F, Noto LV (2016) Climate change effects on the hydrological regime of small non-perennial 5 river basins. Sci Total Environ 542:76-92

Radziejewski M, Kundzewicz ZW (2004a) Detectability of changes in hydrological records. Hydrol Sci J 49(1):39-51

Radziejewski M, Kundzewicz ZW (2004b) Development, use and application of the HYDROSPECT data analysis system for the detection of changes in hydrological time-series for use in WCPWater and National Hydrological Services, WCASP-65, Hydrospect, Version 2.0. User's manual, WMO, Geneva

Raes D (2012) The ETo Calculator. Reference Manual Version 3.2. FAO UN, Rome, Italy

Rodionov SN, Overland JE (2005) Application of a sequential regime shift detection method to the Bering Sea ecosystem. ICES J Mar Sci 62:328-332

Romanowicz RJ et al (2016) Climate change impact on hydrological extremes: preliminary results from the Polish-Norwegian Project. Acta Geophys 64(2):477-509

Schneider C, Laizé CLR, Acreman MC, Flörke M (2013) How will climate change modify river flow regimes in Europe? Hydrol Earth Syst Sci 17(1):325-339

Sear DA, Armitage PD, Dawson FDH (1999) Groundwater dominated rivers. Hydrol Process 11:255-276

Somorowska U (2006) Wpływ stanu retencji podziemnej na proces odpływu w zlewni nizinnej. Wydawnictwa Uniwersytetu Warszawskiego, Warszawa, pp 1-151 
Stahl K et al (2010) Streamflow trends in Europe: evidence from a dataset of near-natural catchments. Hydrol Earth Syst Sci 14:2367-2382

Stahl K, Tallaksen LM, Hannaford J, van Lanen HAJ (2012) Filling the white space on maps of European runoff trends: estimates from a multi-model ensemble. Hydrol Earth Syst Sci $16: 2035-2047$

Szymczak T (2005) Long-term trends in runoff from small lowland catchements. J Water Land Dev 9:35-57

Tetzlaff D et al (2013) Catchments on the cusp? Structural and functional change in northern ecohydrology. Hydrol Process 27:766-774

Theil H (1950) A rank-invariant method of linear and polynomial regression analysis, 1, 2, and 3. Proc R Neth Acad Sci 53:386-392 53:521-525 53:1397-1412

Whitfield PH et al (2012) Reference hydrologic networks I. The status and potential future directions of national reference hydrologic networks for detecting trends. Hydrol Sci J 57:1568-1579
Wrzesiński D (2010a) Detekcja zmian reżimu hydrologicznego Warty w profilu Poznania w latach 1822-2005. Studia i Prace z Geografii i Geologii 12:135-151

Wrzesiński D (2010b) Przestrzenne zróżnicowanie stabilności reżimu odpływu rzek europejskich. Studia i Prace z Geografii i Geologii 3:1-220

Wrzesiński D (2016) Use of Entropy in the Assessment of Uncertainty of River Runoff Regime in Poland. Acta Geophys 64(5):1825-1839

Wrzesiński D, Tomaszewski P (2010) Stabilność elementów hydrometeorologicznych w Polsce w latach 1951-2000. Studia i Prace z Geografii i Geologii 12:169-185

Yang Z, Zhou Y, Wenninger J, Uhlenbrook S (2012) The causes of flow regime shifts in the semi-arid Hailiutu River, Northwest China. Hydrol Earth Syst Sci 16:87-103 